\title{
Vad är nytt i Nytt straffsystem?
}

Några kritiska synpunkter på nyklassisk straffilosofi

Av professor, fil dr ULLA BONDESON, Lund

\section{Inledning}

Brottsförebyggande rådets utredning Nytt straffsystem: Idéer och förslag (Rapport 1977:7), vilken avlämnats av en arbetsgrupp inom BRÅ, har med rätta rönt stor uppmärksamhet i den kriminalpolitiska debatten. I massmedia har rapportens strafftänkande i första hand kommit att diskuteras, medan juristerna av facket mera tycks ha intresserat sig för de föreslagna reformerna. Jag tänker i denna artikelrecension främst studera dess straffilosofi och samtidig söka analysera hur denna överensstämmer med reformförslagen.

De konkreta reformerna syftar generellt till en sänkning av straffnivån och speciellt till ett minskat bruk av frihetsberövande påföljder. I stort sett har de framförda praktiska reformförslagen mottagits välvilligt. Rapportens straffilosofi, som präglas av allmänpreventiva tankegångar, har däremot väckt mera blandade känslor.

Som positivt bör framhållas att rapporten är välskriven och har uppnått syftet att stimulera till debatt. Jämförd med traditionella statliga betänkanden belyser den på ett ganska okonventionellt sätt hela straffsystemet, både de lege lata och de lege ferenda, och försöker också sätta reformerna i relation till straffrättsteorierna. Till det förtjänstfulla får väl även räknas att arbetsgruppen sökt tillgodogöra sig aktuell forskning inom den s k behandlingsforskningen och kring allmänpreventionen, även om denna uppgift emellanåt synes ha varit väl svår för en ensidigt juridiskt sammansatt grupp.

Rapportens svaghet anser jag ligger i de straffilosofiska avsnitten. Straffprinciperna har enligt mitt förmenande förenklats i rapporten och naturligt nog vulgariserats i den allmänna debatten. Samtidigt bedömer jag det som en risk att rapportens strafftänkande genom slagkraftiga formuleringar, som appellerar till skilda grupper, kan komma att överskugga dess praktiska reformpolitik.

Den för mig väsentliga frågan är just huruvida det finns något samband mellan arbetsgruppens straffilosofi och de föreslagna reformerna. Jag kan föreställa mig att gruppens straffprinciper skulle kunna motivera helt andra reformer, likaväl som att de föreslagna reformerna skulle kunna härledas utifrån helt andra straffprinciper. I den mån i verkligheten bristande koherens föreligger mellan straffprinciperna och reformförslagen, blir nästa fråga, vilken i rapporten lämnas obesvarad, vad som för arbets- 
gruppen är det viktigaste. Det föreligger såvitt jag kan bedöma en risk för att dess åsyftade progressiva straffilosofi kan utnyttjas av politiska grupper som inte delar utredningens reformpolitiska idéer.

Jag inleder artikeln med en presentation av den kriminalpolitiska arbetsgruppen och dess rapport. Efter en kortfattad beskrivning av dess reformförslag övergår jag till att närmare granska dess straffilosofi. Jag diskuterar gruppens beskrivning av den nuvarande kriminalpolitiska verkligheten som dominerad av behandlingsideologin, ifrågasätter dess slutsatser av behandlingsforskningen och analyserar sambandet mellan individualprevention och allmänprevention. Jag diskuterar det forskningsmässiga stödet för allmänpreventionen och ställer frågan om inte den i rapporten framställda alternativa teorin snarare är att betrakta som en ideologi. Jag behandlar några av arbetsgruppens centrala tankar avseende rättvis vedergällning, proportionalitet mellan brott och straff, ansvars- och skuldbegreppen. Dessa problem föranleder mig också att ställa vissa frågor angående den föreslagna kriminalpolitikens grad av rationalitet mera allmänt och utredningens inställning till forskning mera speciellt. Jag inför också distinktionen formell och materiell rationalitet/rättvisa. Gruppens straffidéer relateras även till den klassiska och den nyklassiska straffilosofin. På slutet återkommer jag till frågan om sambandet mellan filosofi och politik.

\section{Presentation av utredningen}

Betänkandet Nytt straffsystem lades fram av BRÅ i november 1977. En i stort sett enhällig kriminalpolitisk arbetsgrupp står bakom förslaget. Gruppen har bestått av ett antal tunga namn såsom f d riksåklagaren, numera rikspolischefen Holger Romander, generaldirektören Bo Martinsson, professorerna Knut Sveri och Hans 'Thornstedt samt lagmannen Carl-Edvard Sturkell; förre statssekreteraren Sven Andersson och rättschefen Per Jermsten har fungerat som ordförande och som sekreterare större delen av tiden hovrättsfiskalen Sten Heckscher (kap 3-7 och del av 11), vilken tillsammans med hovrättsrådet Erland Aspelin (kap 1, 8-10 och resten av 11) varit föredragande vid utformningen av rapporten.

Utöver en omfattande rapport (440 sidor) föreligger ett mera populärt hållet referat (71 sidor), som utarbetats av BRÅ:s informationssekretariat. Referatet har utsänts i 40.000 exemplar. En förkortad version av rapporten har även översatts till engelska (1978, Report no. 5). BRÅ: s kriminalpolitiska budskap har således fått en osedvanligt stor spridning. Gruppens sekreterare har dessutom skickligt förklarat de nya idéerna och bemött kritiska 
synpunkter i dagstidningar och TV samt ställt upp i diskussioner inom ett stort antal organisationer.

Rapporten sägs vara ,avsedd att i en första omgång ligga till grund för en bred diskussion om hur vi vill att vårt straffsystem skall se ut". I en sammanställning av reaktioner i dagspressen på Nytt straffsystem framhåller Aspelin att rapporten fått stor uppmärksamhet i tidningarnas ledare och nyhetsspalter samt att arbetsgruppens förslag i allmänhet fått en positiv framtoning och ofta uppfattats som uttryck för en progressiv utveckling. ${ }^{1}$ ) Betänkandet Nytt straffsystem har trots sin mer idémässiga utformning gått på remiss (tillsammans med ungdomsfängelseutredningens betänkande 'Tillsynsdom, SOU 1977:83), ehuru någon remissammanställning icke kommer att göras enligt uppgift från justitiedepartementet.

Nytt straffsystem inleds med ett utmärkt, längre kapitel som beskriver den historiska bakgrunden till det nuvarande påföljdssystemet före och efter brottsbalkens införande 1965 samt gör en summarisk utvärdering av systemet utifrån verksamhetens kostnader och olika typer av forskning. Efter en redogörelse för påföljdssystemet $\mathbf{i}$ de övriga nordiska länderna följer ett tredje kapitel om "straffsystemet i ett samhällsperspektiv", vilket kan te sig mindre tillfredsställande eftersom det säger ganska lite om den samhälleliga strukturen och dess betydelse för olika strafformer. Därefter kommer vad som måste anses vara ett centralt kapitel om „,preventionsteorier och påföljder“, som ger en relativt detaljerad men ganska allmänt hållen analys av begrepp som allmänprevention, individualprevention och inkapacitering. Trots att rapporten sägs vara ämnad som en idéskrift, innehåller emellertid varken detta eller något annat kapitel vad jag skulle vilja kalla en ingående, sammanhängande presentation av gruppens egen straffilosofi. Detta förefaller mig speciellt anmärkningsvärt med tanke på att man främst säger sig vilja diskutera principfrågor.

De följande kapitlen går mera konkret igenom existerande påföljdsformer och behandlar var för sig frihetsstraffen, kriminalvård i frihet, ekonomiska sanktioner, särregleringar och diskuterar även vissa alternativa sanktioner. I ett slutkapitel behandlas vissa övriga frågor, ofta av mera teknisk karaktär, såsom sanktionskumulation, påföljdskonkurrens, processuella bestämmelser och registreringsfrågor.

Vilka är då huvudpunkterna i Nytt straffsystem? BRÅ : s informationsavdelning har gjort ett sammanfattningsblad som härvidlag kan vara upplysande. Angående den nya straffilosofin heter

1) Erland Aspelin, Reaktioner i dagspressen på Nytt straffsystem, BRÄ-apropả 1978, 24-27. 
det: „Enligt arbetsgruppen bör anspråken på rättvisa, proportionalitet och humanitet ha stort utrymme. Lagbrytaren bör inte behandlas som vårdfall när han inte är sjuk. Strafflagen måste bygga på den enskildes ansvar för sina handlingar. Lagen bör tala klarspråk. Straffet är och måste vara ett obehag. Det skall stå i proportion till brottets svårhet. Det skall kunna förutses och utmätas konsekvent efter brottet och inte efter lagbrytarens sociala situation."

Dessa straffprinciper kompletteras med konkreta riktlinjer och förslag hur det nya straffsystemet bör utformas. Arbetsgruppen har dock icke sett som sin uppgift att utarbeta färdiga lagförslag. Reformförslagen innebär ökat utrymme för framförallt böter men även villkorlig dom. Utöver skyddstillsyn föreslås en ny frivårdspåföljd kallad intensivövervakning. Man eftersträvar färre och kortare frihetsstraff. Ungdomsfängelse och internering bör avskaffas. Man ställer sig avvisande till andra, nya strafformer. En majoritet föreslår att villkorlig frigivning slopas.

\section{Kort diskussion av presenterade reformförslag}

De praktiska reformförslagen är i stort sett rimliga och ligger i tiden. Härmed är också sagt att de inte är påfallande nya. När man föreslår ett minskat bruk av de frihetsberövande påföljderna är givetvis detta utmärkt. Man fullföljer emellertid härvid en i Sverige gammal tradition som kom till uttryck i strafflagberedningen, och förre justitieministern Lennart Geijer gjorde vad han kunde för att påskynda denna utveckling. På senare år har samma tankar förts fram inte bara i våra nordiska grannländer utan även i Europarådet och i Förenta nationerna.

Då arbetsgruppen föreslår ett avskaffande av påföljderna ungdomsfängelse och internering är inte heller detta helt originellt med tanke på att dessa tidsobestämda påföljder till stor del redan slopats i våra grannländer. (Ungdomsfängelse avskaffades i Danmark 1973 och i Norge 1975; internering har huvudsakligen upphävts i Finland 1971 och i Danmark 1973 samt är under omprövning i Norge.) Redan i direktiven till ungdomsfängelseutredningen hette det att man skulle söka efter alternativ till denna påföljd, och i praktiken har domarna gått händelserna i förväg genom att kraftigt minska användningen av påföljden. När utredningens betänkande lades fram (Tillsynsdom, SOU 1977:83), där man föreslår att påföljden avskaffas, hade den i realiteten nästan kommit att upphöra. På motsvarande sätt har antalet domar till internering kraftigt minskat under senare år.

De reformer som skulle kunna betecknas som relativt nya tillhör väl de mera tveksamma. I försöket att avskaffa de tidsobestämda straffen vill gruppen föreslå ett slopande av den villkor- 
liga frigivningen. Här görs dock en reservation av generaldirektören Martinsson. Flera recensenter har också uttalat kritik på denna punkt. ${ }^{2}$ )

Det föreslagna nya frivårdsinstitutet kallat intensivövervakning har inte heller mött någon större förståelse. En sådan anmälningsplikt eller form av poliskontroll torde komma att upplevas som ganska meningslös av såväl övervakare som klienter och definitivt göra det svårare för klienterna att mottaga den hjälp de samtidigt skulle kunna erbjudas och ofta väl behöver. ${ }^{3}$ )

Andra nyare strafformer, vilka förespråkats från olika håll på senare tid som alternativ till fängelsestraff, såsom samhällstjänst, veckoslutsfängelse och nattfängelse, avvisas av arbetsgruppen av principiella skäl. De anses helt enkelt försvåra skapandet av ett enkelt och förutsebart system såsom man föreställt sig det i $\mathrm{Nytt}$ straffsystem.

\section{Kritiska synpunkter på straffilosofin}

\subsection{Inledande om preventionsteorier}

Det är bra och riktigt då gruppen föreslår att straff inte bör kallas för behandling och att straffen inte bör göras mera kännbara med hänvisning till ett behandlingsbehov hos den dömde än som eljest rent straffmässigt kan motiveras. Det kan dock förefalla som om arbetsgruppen här slår in öppna dörrar. Tanken att man bör skilja mellan straff och behandling fördes med skärpa fram av bl a de norska sociologerna Aubert och Christie mot slutet på 50-talet och av amerikanska kriminologer som Cressey ungefär samtidigt. Senare empirisk forskning har med all tydlighet visat att straff, även om de eufemistiskt kallas behandling eller vård, inte har önskvärd individualpreventiv effekt.4) Kionkreta exempel på att man dragit kriminalpolitisk lärdom härav är att de tidsobestämda straffen avskaffas i form av

$\left.{ }^{2}\right)$ Björn Kjellin och Ivar Strahl har kritiserat tanken att avskaffa den villkorliga frigivningen i SvJT 1978, s 130 resp 133 . Se även Knud Waaben, SvJT 1978, s 223 och Pr $\varnothing$ vel $\varnothing$ sladelse, NTfK 1977, s 137 -154. Inkeri Anttila har beskrivit hur förebilden till ett alternativt förslag vad gäller utformningen av den villkorliga frigivningen har hämtats från Finland, där förslaget redan genomförts, SvJT 1978, s 123.

3) Ulla Bondeson, Kriminalvård $i$ frihet - intention och verklighet, Stockholm 1977, kap 7 och 9. Se även Kriminalforsorg - Socialforsorg, Justitsministeriet, K $\phi$ benhavn 1975:752 (vol 1-3) och Kriminalomsorg i frihet, NOU 1975:61.

4) För en sammanfattning av främst den amerikanska behandlingsforskningen se Linton, Martinson \& Wilks: The Effectiveness of Correctional Treatment, New York 1975. För svenska förhållanden se Bondeson, Argot Knowledge as an Indicator of Criminal Socialization, Scandinavian Studies in Criminology 1968, 73-107, Fången $i$ fångsamhället, Stockholm 1974 och opus cit 1977 samt häri angivna litteraturreferenser. 
behandling på ungdomsanstalter och interneringsanstalter liksom att de icke tidsbestämda fängelsestraffen håller på att försvinna (systemet med straff som inom vida gränser lämnas obestämt $\mathbf{i}$ domen har $t$ ex övergivits i flera stater i USA). Men det är givetvis värdefullt att arbetsgruppen samlat dessa kriminalpolitiska reformidéer, vilka klart innebär ett nytänkande i relation till brottsbalken.

Men gruppen nöjer sig inte med att reagera mot de uppenbara överdrifter som den $\mathrm{s} k$ behandlingstanken lett till inom kriminalpolitiken. Den tycks faktiskt kasta ut alla hänsynstaganden till den s k individualpreventionen, vilket är ett vida större steg. Vad gäller individuell avskräckning påpekas säkert helt riktigt att det finns inget som talar för ett bestämt samband mellan påföljdens stränghet och dess individuellt avskräckande effekt, och att det därför knappast finns grund för att tillmäta förfinade överväganden rörande olika påföljders individuellt avskräckande effekt någon självständig betydelse vid straffsystemets utformning (s 186-188). Av olika skäl, som utförligt redovisas, anser man inte heller att inkapacitering behöver tillmätas någon självständig betydelse inom påföljdssystemet (s 188-196).

Det kriminalpolitiska beslutsfattandet skall vara rationellt och syftet med straffet sägs vara prevention: "Straffsystemets legitimitet grundas på önskemålet att förhindra vissa handlingar" (s 196). Sedan således individualpreventionen avrättats, återupplivas allmänpreventionen. Samtidigt som man gör en uppvärdering av allmänpreventionen, i kombination med proportionalitet, förespråkar man ett straffsystem som skall ta större hänsyn till humanitet och rättvisa. Hur lyckas då arbetsgruppen med denna ekvilibristiska akt?

Kapitlet angående preventionsteorier saknar inte nyanseringar. Man skulle t $0 \mathrm{~m}$ kunna påstå att det är författat på ett så plastiskt språk, med så många av invändningarna redan bemötta och med så många reservationer att kritiken lätt kommer av sig. Det sägs exempelvis att straffrätten skall påverka medborgarnas värderingar, men gruppen är väl medveten om att den i själva verket gör det dåligt och att andra faktorer har större betydelse. Man gör en „försiktig uppvärdering av allmänpreventionen“ (s 199), fastän man vet att forskningsunderlaget för allmänpreventionsteorin är svagt. Man förespråkar en kombination av ett allmänpreventivt synsätt och större humanitet, trots att man är medveten om att allmänpreventionen normalt associerar till stränga straff och individualpreventionen till mildare behandling. Mycket är således motsägelsefullt. Jag skall emellertid försöka diskutera vad som kan uppfattas som rapportens huvudsakliga budskap och härvid sätta frågetecken för några av dess slutsatser. 


\subsection{Verklighetsbeskrivning}

Det är för det första tveksamt om påföljdssystemet faktiskt utmärkts av individualpreventionen på det sätt som rapporten gör gällande. Det heter: ,Individualpreventiva tankegångar har präglat de västerländska straffsystemens utveckling under ungefär 100 år“ (s 175). Och: „Få länders straffsystem har präglats av behandlingstanken i lika stor utsträckning som det svenska“ (s 177).

Det förefaller mig vara en felaktig verklighetsbeskrivning då gruppen påstår att individualpreventionen präglat den svenska kriminalpolitiken i så hög grad som här hävdas. ${ }^{5}$ ) Det kan knappast vara okänt för arbetsgruppens praktiserande juridiska ledamöter att de flesta straff här i landet faktiskt utmätes traditionellt just på det sätt som gruppen förespråkar att man bör göra. ${ }^{6}$ ) I rapporten görs endast följande, mer preciserade reservation: ,I det ökande antalet situationer där påföljden bestäms till böter har behandlingssynpunkter föga utrymme“ (s 177). Ett klargörande tycks här vara på sin plats. För den stora majoriteten av brott döms sedan lång tid till böter och där har behandlingssynpunkter inget utrymme. Dessa s k taxebrott torde komma arbetsgruppens ideal om allmänprevention och proportionalitet mellan brott och straff så nära det överhuvud är möjligt. Men även vid en stor del av fängelsestraffen föreligger det utöver lagens strafflatituder, vilka sätter absoluta gränser för individualpreventiva hänsynstaganden, en relativt fast straffmätningspraxis varigenom brottens svårhet översätts till de aktuella frihetsstraffens längd. Det gällde i hög grad lydnadsbrotten och torde vara tillämpligt vid större delen av rattfylleribrotten samt en hel del av de svårare stöld- och bedrägeribrotten, misshandelsbrotten och narkotikabrotten. Det saknas emellertid i Sverige forskning kring faktorer bakom domarnas straffmätning.

Som jag ingående redogjort för i annat sammanhang kom strafflagberedningens mer individualpreventivt färgade reformförslag att blandas upp med allmänpreventiva moment i brottsbalken även för de mer individualpreventivt motiverade påföljderna villkorlig dom och skyddstillsyn. ${ }^{7}$ ) Att domarna inte ens vid valet mellan dessa påföljder i första hand tycks se till de dömdas behandlingsbehov har jag visat i en systematisk analys av olika personliga och sociala variabler respektive brottsfaktorer i ett slumpmässigt urval dömda till dessa påföljder. ${ }^{8}$ ) Utfallet av

5) Se även Kjellin, opus cit s 129 och Strahl, opus cit s 132.

6) Se även Waaben, Frihedsstraffens plads i fremtidens strafferet, 28. nordiske juristmøde 1978, s 13.

7). Bondeson, opus cit 1977, kap 3 (sammanfattning s 71 och 90).

8) Ibid, kap 4 (sammanfattning s 139-141). 
denna statistiska analys kan sägas överensstämma med von Eybens observationer att domstolarna vid straffmätningen tar hänsyn till i första hand två faktorer, nämligen svårhetsgraden hos det aktuella brottet och tidigare brott. ${ }^{9}$ )

Arbetsgruppen förefaller således delvis att slåss mot väderkvarnar. Rapporten ger vidare intryck av att den s k behandlingstanken i allmänhet lett till längre omhändertaganden än vad som skulle blivit följden av ett rent strafftänkande. Inga data presenteras emellertid för svenskt vidkommande som styrker detta påstående. Ett exempel som brukar anföras är ungdomsfängelse. Här har dock ungdomsfängelseutredningen visat att frihetsberövandet i regel skulle ha blivit längre om fängelse i stället hade utdömts. Detta förhållande framgår också av rapporten, men det hävdas ändå att ,,det finns uppenbara risker för att $t$ ex frihetsberövanden och kontroll i frihet blir längre och mer ingripande när de grundas i en behandlingstanke“ (s 180). Som enda stöd härför åberopas fängelsetider från Kalifornien. Det kan härtill sägas att om intagningstiderna där ökade samtidigt med införandet av behandlingstanken, synes dessa inte ha förkortats då den obestämda tiden senare avskaffades. I Sverige skulle däremot internering kanske kunna ses som ett exempel på att behandlingstanken lett till längre frihetsberövanden.

\subsection{Behandlingsforskning}

Den åberopade behandlingsforskningen ges en kortfattad men ganska nyanserad beskrivning i inledningskapitlet (s 72-78), medan de slutsatser som dras härav i preventionskapitlet förefaller mig något förhastade (s 183-184). Det påpekas först sakligt att invändningarna mot ett behandlingsorienterat påföljdssystem skulle väga mindre tungt om det kunde påvisas eller göras sannolikt att en behandling visade sig vara mer effektiv än någon annan. Behandlingsforskningen sägs emellertid inte uppvisa sådana resultat: "Som sammanfattning av i olika länder — inklusive Sverige - gjorda undersökningar kan man konstatera att ingen behandlingsmetod mer än någon annan märkbart och återkommande minskar risken för återfall.“ (s 183)

Internationellt har man ofta konkluderat att olika behandlingsformer ger likartade resultat, men som jag påpekat $i$ en utvärdering av den nordiska behandlingsforskningen bygger den amerikanska $i$ huvudsak på mindre variationer av behandlingen inom en given påföljd. ${ }^{10}$ ) De undersökningar som gjorts i Sverige angående den individualpreventiva effekten av olika påföljder till-

9) von Eyben, Strafudmåling, Kфbenhavn 1950.

10) Bondeson, Evaluation of Correctional Treatment in Crime Deterrence and Offender Career, eds. Haag \& Martinson, New York 1975. 
hör de internationellt sett mest omfattande och ingående i sitt slag, och de visar tvärtemot signifikanta skillnader i återfall mellan olika påföljdsgrupper, med hänsyn tagen till påföljdsgruppernas varierande belastningsgrad. Det är vidare intressant att observera att de studier som finns angående utvärderingar av olika påföljder har gett relativt likartade resultat, nämligen att mer ingripande åtgärder gett sämre resultat. Enligt tidigare svenska undersökningar skulle frihetsberövande påföljder ge sämre resultat än icke-frihetsberövande ${ }^{11}$ ), längre frihetsberövanden sämre resultat än kortare vid alla typer av frihetsstraff ${ }^{12}$ ), skyddstillsyn med anstaltsbehandling sämre resultat än utan anstaltsbehandling och skyddstillsyn sämre resultat än villkorlig $\left.\mathrm{dom}^{13}\right)$. Dessa resultat överensstämmer också med den kände behandlingsforskaren Wilkins' konklusion efter dennes systematiska genomgång av behandlingsforskningen: „Den enklaste hypotes som kan uppställas som en tolkning av resultaten är att ju mindre vi kan göra med lagbrytare desto bättre".${ }^{14}$ ) Dessa studier ges en korrekt presentation i rapporten s 78 men framställs på ett missvisande sätt $\mathbf{s} 184$. Där heter det bl a att ,,andra resultat talar i annan riktning“", varvid hänvisas till en BRÅ-rapport där någon prediktionsteknik icke används för att göra påföljdsgrupperna jämförbara. Konklusionen lyder: „De små och omdiskuterade skillnader i verkningarna mellan olika sanktionsformer som kan finnas är i varje fall under inga omständigheter tillräckliga för att motivera att påföljdssystemet skall vara utformat enligt en behandlingsmodell. Själva grunden för denna individualpreventiva teori framstår som ohållbar." ${ }^{15}$ )

Texten är i detta citat liksom i hela det omgivande stycket glidande. Det är riktigt att forskningsresultaten inte stöder en behandlingsmodell, men därmed är ingalunda sagt att de saknar intresse för tolkningen av den individualpreventiva teorin. Arbets-

11) Bengt Börjeson, Om påföljders verkningar, Uppsala 1966.

12) Bondeson, opus cit 1974.

13) Bondeson, opus cit 1977.

14) Leslie Wilkins, Evaluation of Penal Measures, New York 1969 (citat s 83).

15) De skillnader som konstaterats i verkningarna mellan olika sanktionsformer kallas i Nytt straffsystem godtyckligt för „små “ (s 184), utan att deras verkliga storleksordning anges. I samhällsvetenskapliga sammanhang brukar emellertid inte signifikanta skillnader på $20-$ $30 \%$ rubriceras som små, vare sig statistiskt eller socialt sett. Att resultat är „omdiskuterade“ behöver heller inte betyda att de är diskutabla i betydelsen tvivelaktiga. I rapporten omnämns ensidigt ett
BRÅ-PM där en tolkning av vissa resultat har diskuterats, medan författarens genmäle till detta inlägg inte refereras (se Bondeson, opus cit 1977, s 411-412). Inte heller omnämns att Börjeson besvarat sina kritiker och att uppföljande, oberoende forskning som gjorts av Börjesons data gett stöd åt dennes slutsatser. 
gruppen tycks sitta fast i behandlingstanken såtillvida att den endast kan tolka individualpreventionen positivt, nämligen genom att anta att lagstiftarens positiva syfte med behandlingen kan uppfyllas respektive icke uppfyllas. Vad jag kallat teorin om den negativa individualpreventionen, nämligen tanken att straffet i stället kan öka risken för återfall, tycks man ha svårt att förstå, åtminstone teoretiskt. Utifrån common-sense antaganden sägs visserligen ofta $\mathrm{i}$ rapporten att straffet försvårar den sociala anpassningen för brottslingen (se tex s 186), men man tycks inte koppla ihop denna observation med den individualpreventiva teorin. Om teorin om den negativa individualpreventionen är riktig, kan vi inte kasta ut individualpreventionsteorin som varande ointressant. Vi tvingas i stället omvärdera denna utifrån de observerade negativa förtecknen. Vagt och oklart kan man säga att behandlingen „,misslyckats“, men det är en väsentlig skillnad om en positiv effekt uteblivit eller om effekten blivit negativ. Jag kommer senare att ge exempel på de skilda implikationer som följer av denna distinktion.

\subsection{Samband individual- och allmänprevention}

Arbetsgruppen känner ett behov av att ge den straffande verksamheten någon legitimitet. Man griper således efter de allmänpreventiva teorierna, sedan man förkastat de individualpreventiva teoriernas hållbarhet och berättigande: „Vad som hänt under de senaste 15 åren är nämligen att dessa har visat sig vara de kanske mest tvivelaktiga av de principer som brukar begagnas. I en sådan situation ligger det nära till hands att söka motiven till straffsystemet $\mathrm{i}$ de skäl som brukar anses vara den andra tänkbara grunden" (s 161).

$\mathrm{Nu}$ finns det emellertid logiskt sett inga enkla eller självklara samband mellan förkastande av individualpreventionen och accepterande av allmänpreventionen som teorier betraktade, inte ens om vi utgår från noll-korrelationer mellan åtgärder och effekter. Jag har tidigare mer utförligt redogjort för olika tolkningar av att individualpreventionen „,misslyckats“, beroende på om vi uppfattar teorin deskriptivt eller normativt. ${ }^{16}$ ) Frågan om det föreligger individualpreventiva effekter eller inte har knappast någon relevans för allmänpreventionsteorin betraktad som en uppfattning om hur verkligheten faktiskt ser ut - huruvida en påföljd ger individualpreventiva respektive allmänpreventiva effekter är tvá olika frågor. Endast under de förutsättningarna att vi måsle uppge ett rationellt syfte med straffet, att individualpreventionsteorin hade förkastats såväl deskriptivt som normativt och att allmänpreventionsteorin vore det enda alternativet

16) Bondeson, opus cit 1977, s 334 och 419. 
till individualpreventionsteorin, skulle allmänpreventionen relativt sett bli ett starkare argument.

\subsection{Allmänpreventionen - teori eller ideologi?}

Inom arbetsgruppen har man sålunda varit medveten om att det vetenskapliga stödet för allmänpreventionsteorin är ganska svagt (s 162). Utifrån BR $\AA$ : s rapport General Deterrence framhåller man att ,,allmänpreventionens förespråkare är mera lågmälda nu än förut" (s 163). Det sägs vidare att man betonar andra aspekter nu än tidigare: ,Det direkta straffhotet, avskräckningen, har trätt i bakgrunden. Man har i stället betonat strafflagen som ett auktoritativt uttryck för en accepterad moral - med den verkan på människors handlingssätt detta må ha“ (s 163). Allmänprevention genom moralbildning har i Sverige dock tidigare behandlats av Lundstedt, Ekelöf och Olivecrona. Någon systematisk genomgång av de empiriska studier som gjorts beträffande allmänpreventionen har man inte låtit utföra. Andenaes refereras naturligt nog, men den utförliga genomgången av teori och empiri hos Zimring \& Hawkins omnämns exempelvis ej. ${ }^{37}$ )

Man kan lägga märke till att medan effektivitetsresonemang var ett avgörande argument för gruppen vid förkastande av individualpreventionen, så tycks motsvarande resonemang inte vara ett viktigt skäl för att acceptera allmänpreventionen. Det sägs klart att ,,man har mycket begränsade kunskaper om hur effektivt allmänpreventionen verkar" (s 162). Men inte nog härmed. Man säger för säkerhets skull också att ,,det är tveksamt om det någonsin kommer att bli möjligt att göra vetenskapligt underbyggda påståenden om den saken" (s 162). De juristlärda framhåller för eventuellt forskningsintresserade beteende- och samhällsvetare att det är ,förenat med mycket stora metodologiska problem att bedriva forskning om allmänprevention" (s 162).

Allmänpreventionen tycks alltså införas för att ge legitimitet åt den straffande verksamheten, som härmed verkar rationell genom att den sägs bygga på prevention. Men samtidigt låter gruppen förstå att detta effektivitetsresonemang inte skall kunna diskonfirmeras genom empiriska undersökningar i likhet med

17) Johannes Andenaes har genom sina artiklar om allmänpreventionen (till dels samlade i volymen Straff og lovlydighet, Oslo 1974; se även Nyere forskning om almenprevensjonen - status og kommentar, NTfK 1977, 61-101) och gästföreläsningar vid amerikanska universitet stimulerat såväl det teoretiska som i synnerhet det empiriska intresset kring dessa frågor. Denna tacksamhetsskuld erkänns också av Franklin Zimring \& Gordan Hawkins, vilka sammanställt och försökt analysera en stor del av den åtminstone tidigare forskningen på området $\mathrm{i}$ boken Deterrence, Chicago 1973. 
individualpreventionsteorin - därtill är problemen alltför komplexa eller forskningsmetodiken alltför outvecklad.

För säkerhets skull knyter man dessutom allmänpreventionen till andra värden än de preventiva. Man talar härvid om rättvisa, proportionalitet, humanitet och rättssäkerhet (s 163-164). Allmänpreventionen blir härmed mindre en vetenskaplig teori än en ideologi $i^{18}$ ) och hänvisningar härtill mera rationaliseringar än rationella argument. ${ }^{19}$ ) De nämnda värdena har givitvis en positiv klang och kan användas för att legitimera, t o m en eventuellt av andra skäl önskad straffideologi. Signifikativt nog citeras Mäkelä utan någon som helst kommentar när han deklarerar att strafflagens uppgift är att ,reproducera själva den officiella moralen och därigenom sig själv, alltså upprätthålla sig själv“ (s 170).

\subsection{Vedergällning}

Arbetsgruppen rehabiliterar även vedergällningsbegreppet. Gränsen mellan den absoluta och de relativa straffteorierna tycks därmed utsuddas. I och med att man återinför en $\mathrm{s} k$ absolut straffteori såsom vedergällning har man i själva verket lämnat de egentliga straffteorierna och övergått till ideologins område. Det heter t ex i rapporten att påföljden skall vara ,en för lagbrytaren obehaglig reaktion på en förbjuden handling“ och ,detta kan tolkas som ett moment av hämnd. Detta inslag i straff'systemet förefaller of rånkomligt och knappast orimligt" (s 171). Man vill endast avvisa den vedergällning som innebär att „,hämnden är oproportionerlig i förhållande till den ogärning den följer på“. „Däremot kan inte ett medvetet, avsiktigt - men kontrollerat - obehag vars omfattning bestäms med utgångspunkt från brottets grovhet vara oförenligt med ett civiliserat straffsystem. Det element av vedergällning som kan förbindas med ett allmänpreventivt system — nämligen viss proportionalitet i förhållande till gärningens svårhet - är i detta fall godtagbart.“ (s 172) $\left.{ }^{20}\right)$

\subsection{Proportionalitet}

I själva verket kan proportionalitetsprincipen mer än allmänpreventionsteorin ses som kungstanken i arbetsgruppens straffilosofi. Denna ständigt omnämnda princip görs emellertid inte till

18) Vilhelm Aubert, Allmänpreventionen - teori eller ideologi i Kontroll av individen, red Åkerman, StockhoIm 1972.

$\left.{ }^{19}\right)$ Bondeson, Inledning till rationalitetstemat $\mathrm{i}$ Rationalitet $i$ rättssystemet, red Bondeson, Stockholm 1979.

${ }^{20}$ ) För en analys av begreppet vedergällning se $t$ ex Ingemar Hedenius, Om människans moraliska villkor, Författarförlaget 1972, 148181. 
föremål för någon närmare analys. Att på ett rättvist sätt fastställa relationen mellan brott och straff är emellertid ingen enkel sak. Vi kan inte i likhet med den tyska straffilosofin från föregående århundrade falla tillbaka på några metafysiska åskådningar om brottens inneboende avskyvärdhet.

Den första uppgiften blir att söka fastställa de olika brottens $s k$ straffuärden. Enligt vilka kriterier skall dessa bestämmas? Enligt den skada de orsakar samhället eller individen? Eller enligt någon sorts skuldprincip? Beklagligtvis förs i rapporten ingen diskussion angående val av kriterier beträffande brottens straffvärde.

Arbetsgruppen tycks åtminstone delvis ha insett att det inte är någon lätt uppgift att objektivt gradera straffen efter någon stränghetsprincip; gruppen kritiserar således strafflagberedningen och BrB för att inte strikt ha graderat påföljderna efter inbördes stränghet (s $206 \mathrm{ff}$ ) men tycks inte heller kapabel att lösa problemet på ett enligt den själv helt godtagbart sätt (s 408). Än vanskligare blir det emellertid att subjektivt mäta straffens lidandegrad, dvs för enskilda lagbrytare eller laglydiga. Beträffande dagsböter har lagstiftaren sökt införa ett hänsynstagande till den dömdes ekonomiska situation, och mot denna typ av individualisering protesterar icke arbetsgruppen. Skulle vi söka införa motsvarande vad gäller fängelse och ta hänsyn till hur mycket den straffade går miste om under den tid han berövas friheten? Konsekvensen härav skulle bli att den ekonomiskt mera välbeställde skulle dömas till kortare dagsfängelsetider. Detta kanske något drastiska exempel visar vilka svåra överväganden man ställs inför då den till synes så enkla proportionaliteten skall fastställas. Det förefaller mig som om man i rapporten inte tillräckligt beaktat eller sökt analysera de svårigheter som är förknippade med att skapa rättvisande relationer mellan två så svårmätbara enheter som brottets svårhet och straffens lidandeskala.

Arbetsgruppen har också gjort det lätt för sig genom att avstå från att göra konkreta försök att fastställa denna rättvisa proportionalitet. Som Törnudd framhållit utifrån arbetet med den s k stomplanen i den finska straffrättskommitténs betänkande är det ,inte svårt att formulera vackert klingande paroller om straffbarheten, men först då man i det konkreta lagberedningsarbetet tvingas ställa olika principer mot varandra, tilldelas dessa principer sin relativa vikt och ett reellt innehåll"“. ${ }^{21}$ )

Den forskningsskeptiska attityd som delvis ges uttryck åt i Nytt straffsystem framkommer också här, då man undviker att diskutera vilka metoder som skulle kunna användas för att söka

21) Patrik Törnudd, Ett halvfärdigt strafflagsförslag, NTfK 1977, 279 -287 (citat s 279). 
komma fram till vad som allmänt skulle kunna uppfattas som ett rättvist straff. Man talar genomgående om att överensstämmelse måste finnas med allmänhetens rättsmedvetande ( $\mathrm{se} t \mathrm{ex}$ s 144 ff), men man förordar inte att intervjuundersökningar utförs som ett led i kartläggandet av allmänhetens rättsliga kunskaper och attityder. Liksom när det gäller allmänpreventionen kan man få intrycket av att sådana undersökningar snarast är mindre önskvärda. Det görs endast någon knapphändig hänvisning till dylika studier, vilken åtföljs av det i sammanhanget något mästrande påpekandet att ,,det är svårt att bedriva sådan forskning på ett vetenskapligt tillfredsställande sätt" (s 153).22) Jag hoppas att dylika formuleringar ,smugit“ sig in i rapporten utan att arbetsgruppen som helhet skulle vilja skriva under på dem.

I själva verket bör dylika intervjuundersökningar vara nödvändiga redskap om man vill veta något om strukturen och innehållet $\mathrm{i}$ det rättsmedvetande som gruppen ständigt hänvisar till. Man tycks i rapporten utgå frăn $\mathrm{sk}$ consensus-antaganden, dvs att allmänhetens rättsmedvetande är uniformt. Att det allmänna rättsmedvetandet $\mathrm{i}$ denna mening är en legal fiktion har jag emellertid visat $i$ annat sammanhang. ${ }^{23}$ ) Om man vill studera i vad mån det hos den allmänna opinionen finns stöd för en kriminalisering och dess omfattning eller om en kriminalisering kan åstadkomma det moraliska avvisande man eftersträvar, blir upprepade intervjuer den enda möjligheten att kontrollera om lagstiftningsåtgärden betraktas som legitim i stora grupper av befolkningen och det enda sättet att mäta om de avsedda attitydeffekterna faktiskt uppnås.

\subsection{Broltslingens personliga egenskaper}

Enligt proportionalitetsprincipen föreslår arbetsgruppen vidare att domstolen skall bortse från brottslingens personliga egenskaper och vid påföljdsvalet (endast?) ta hänsyn till brottet. På denna väsentliga punkt är rapporten dock något oklar, och man kan förmoda att det varit delade meningar härom i gruppen. (Som det heter i förordet: „Meningsskiljaktigheter kan bestå utan att det framgår av rapporten.")

22) En liknande kritisk attityd till forskning kring det allmänna rättsmedvetandet avslöjades av uppsalajuristerna vid det nordiska symposiet i Tällberg angående upprepad brottslighet (se även Lena Holmqvist, Sammanfattning av diskussion, NTfK 1976, s 326-327). En sådan inställning kontrasterar skarpt mot den vikt man fäster vid denna typ av forskning i andra länder, vilket bl a dokumenterades vid Europarådets 13: e kriminologiska forskarkonferens kring temat Public Opinion on Crime and Criminal Justice, Strassbourg 1978.

${ }^{23}$ ) Bondeson, Det allmänna rättsmedvetandet - en legal fiktion i red Bondeson, opus cit 1979. 
Man vill minska betydelsen av personundersökningar och skriver ganska otvetydigt i samband härmed: „Uppgifter om den misstänktes person skall nämligen i princip inte påverka domstolen vid valet av påföljd“" (s 428). (Uppgifter om den personliga och sociala situationen sägs däremot kunna vara av intresse under verkställighetsstadiet.) Samtidigt vill man negligera invändningen att ett system, som innebär att brottet helt kommer i centrum vid bedömningen, skulle kunna präglas av ,stelhet och omänsklighet i sin praktiska tillämpning" (s 173). I detta sammanhang tar man emellertid i rapporten hänsyn till de personliga faktorerna $\mathrm{i}$ samband med en $\mathrm{s} k$ skuldfördelningsprincip. Det hävdas härvid något motsägelsefullt: ,Storleken av gärningsmannens skuld beror huvudsakligen på vilket brott han har begått. Motivet och brottssituationen är dock också högst relevant. Därigenom kan en bedömning av gärningsmannens personliga villkor få betydelse när storleken av skulden skall bestämmas.“ (s 173)

I en recension har Geijer uppfattat tanken att brottet skall sättas i förgrunden, inte gärningsmannen, som ,ett jättekliv tillbaka“. Genom att domarens verksamhet blir rent ingenjörsmässig, görs en prokrustessäng av systemet. ,Man kommer att tänka på historien om svenskamerikanen som skröt med att i Amerika fanns det rakautomater. Man la i 10 cent, stack ner hakan och blev rakad. Men alla har väl inte samma hakor, sa den förvånade svensken. Nä, sa svenskamerikanen, men dom får.“" ${ }^{24}$ )

\subsection{Ansvar och skuld}

Utifrån allmänpreventionsteorin och proportionalitetsprincipen blir begrepp som ansvar och skuld helt centrala. Begreppen brukas flitigt och tas för givna utan att underkastas någon närmare analys. Den filosofiska diskussion som dessa synnerligen svåra begrepp orsakat förbigås i tystnad. ${ }^{25}$ ) Gruppen menar att ,behandlingstanken ... tenderar att beröva lagbrytaren ansvaret för sitt handlande“ (s 183). Den deklarerar högtidligt att genom moralbildning ,har straffrätten och den därmed förknippade skuldprincipen bl a som uppgift att med utgångspunkt i officiella värderingar fördela moraliskt ansvar och skuld i samhället“ (s 169)..$^{26}$ )

24) Lennart Geijer, Nytt straffsystem — Ett jättekliv tillbaka! LOtidningen 1978, s 12 .

${ }^{25}$ ) Se t ex Alf Ross, Skyld, ansvar og straf, København 1970 (spec kap Om determinisme og moral) och Hedenius, opus cit 1972 (spec kap om Viljans frihet).

26) Dagens Nyheter har i en ledare (24/11 1977) hävdat att tron att behandlingstanken och vård skulle stå i motsatsförhållande till personligt ansvar är en ren myt: „, Under sökandet efter en ny idé har man råkat gräva upp ett lik." 
Det är givetvis riktigt att ,strafflagen bygger dogmatiskt sett på ett ansvarsbegrepp“ (s 154), ehuru intressanta försök har gjorts att avskaffa det juridiska skuldbegreppet vilka i sammanhanget kunde omnämnts. Den vetenskapsteoretiska bakgrunden till dessa experiment, nämligen att kriminologins möjligheter att förklara brottet med hjälp av biologiska, psykologiska och sociologiska faktorer i motsvarande grad minskar utrymmet för ett metafysiskt skuldbegrepp, hade åtminstone varit värd en diskussion. ${ }^{27}$ ) Man kan som rapporten hävda att de flesta enskilda brottsfaktorer haft ett relativt lågt förklaringsvärde (s 182), men det bör påpekas att sammantagna blir det totala förklaringsvärdet väsentligt högre. Det torde åtminstone inte finnas studier som visar att $\mathrm{s} \mathrm{k}$ viljefaktorer — vilket ett $\mathrm{s} \mathrm{k}$ ansvarstänkande måste vila på - - bättre skulle kunna förklara brottsligt beteende än gängse beteendevetenskapliga och samhällsvetenskapliga faktorer. ${ }^{28}$ )

Trots att rapporten uppger straffets syfte vara prevention, diskuterar den knappast brottets orsaker för att rationellt söka anpassa ett preventivt tänkande till ett orsakstänkande. Detta är naturligtvis en stor fråga som utredningen antagligen funnit vara alltför svår för att kunna behandlas inom tillgängligt utrymme.

\section{Rättvisa och rationalitet}

Arbetsgruppen talar mycket om rättvisa straff och tycks härmed mena att alla brott skall bestraffas, att de skall bestraffas efter brottets grovhet och att samma brott skall få samma straff. Detta kan ju låta både rättvist och rationellt, så länge principerna förblir abstrakta och inte konfronteras med verkligheten. Med den kunskap vi i dag förfogar över angående den dolda brottsligheten avseende såväl låga upptäckts- som uppklaringsfrekvenser, vet vi emellertid att tanken att ,straffet skall komma regelbundet" (s 190) är en fiktion vi inte längre kan laborera med.

Vi kan heller inte bortse från det förhållandet att människor har olika personliga och sociala förutsättningar. Marx menade $t$ ex att man inte kan skapa rättvisa straff $i$ ett orättvist samhälle. Vi vet i dag att straffen normalt drabbar de socialt sämst ställda, som ofta redan är straffade med ett dåligt socialt arv och senare i stor utsträckning blir utstraffade av straffsystemet. Vad är det då för rättvisa i att ge dessa olyckliga människor kännbara straff, som skall vara obehagliga och ständigt trappas upp?

Weber gjorde en viktig distinktion mellan formell och mate-

27) Se t ex Leon Radzinowicz, Ideology and Crime, London 1966.

28) Leif Persson, Målsättning, logik, medel och effektivitet inom det kriminalpolitiska systemet i Bondeson red, opus cit 1979. 
riell rättvisa/rationalitet. Det förefaller som om man i arbetsgruppen endast haft den formella rättvisan i åtanke, och det tror jag är en av anledningarna till att man hamnat så snett. Weber kom själv trots sin distinktion att betona den formella rationaliteten på den materiellas bekostnad, vilket $t$ ex fick honom att se den tyska begreppsjurisprudensen som ett uttryck för juridikens högsta rationalitetsstadium..$^{29}$ )

Det bör vidare framhållas att den bild rapporten ger av lagstiftarens möjligheter att styra allmänhetens rättsmedvetande och domarens straffmätning förefaller kraftigt överdriven. Naturligtvis varnas för alltför stora förväntningar på lagen som styrmedel. Ändå utgår man från att domaren avgör frågor om påföljdsval och straffmätning enligt rationella beslutsmodeller. Det förefaller mig vara en form av överintellektualisering som leder till felaktiga slutsatser om möjligheten att utforma kriminalpolitiken enligt vissa givna teorier.

Enligt flera bedömare har traditionen mer än någon form av rationella argument påverkat påföljdssystemets faktiska utseende, även i dess hittillsvarande mer individualpreventivt färgade utformning. ${ }^{30}$ ) Von Eyben fann tex i sin undersökning visserligen olikheter i straffmätning mellan enskilda domare men samtidigt likheter mellan domslut i olika länder, vilket kan tolkas så att praxis utformas oavsett exakta lagbestämmelser och mer bestäms av traditionella och emotionella faktorer än av rationella. Han kunde likaså visa hur förändringar i lagstiftningen inte slog igenom i domarens straffmätning. Sådana resultat fick von Eyben att konkludera att strafflatituderna borde avskaffas.

Det torde vara signifikativt att då man i Nytt straffsystem diskuterar strafflatituder och deras betydelse som moralbildande instrument, behandlar man inte vare sig von Eybens studie eller andra empiriska studier som visar stora variationer i straffmätningen. ${ }^{31}$ ) Man förordar enligt min uppfattning något optimistiskt snävare straffskalor och införande av straffmätningsregler. Det kan t ex nämnas att von Eybens undersökning i huvudsak bygger på danska domslut där domaren redan haft tillgång till vissa sådana straffmätningsregler.

Cressey har $i$ en intressant artikel beskrivit hur de verkställande organen i olika tider och på olika plan sett som sin uppgift anpassa lagstiftarens alltför höga straffnivå till vad som kan upp-

$\left.{ }^{29}\right)$ Bondeson, Inledning till rationalitetstemat i Bondeson red, opus cit 1979 .

$\left.{ }^{30}\right)$ Se även Stephan Hurwitz. Strafudmåling, NTfK 1950, 197-200 (spec s 200), Ivar Strahl, Om straffutmätning, SvJT 1951, 401-422 (spec s. 416) och Andenaes, Straffmåling, NTfK 1958, 170-184 (spec
s 172).

31) Se t ex Bondeson, opus cit 1977, s 98-104. 
fattas som rimliga straff. Han betraktar även det amerikanska systemet med ,plea-bargaining“ som ett sätt att skipa rättvisa genom att sänka straffnivån; ${ }^{32}$ ) för att tala med Weber skulle de materiella rättvisekraven endast kunna tillgodoses genom att man bortser från de formella.

\section{Klassisk och nyklassisk straffilosofi}

Rapporten utmärks i det straffilosofiska avsnittet av en viss brist på historiskt och strukturellt perspektiv som bl a tar sig uttryck $\mathbf{i}$ att den inte beskriver olika straffteorier som system betraktade, än mindre relaterar dessa till rådande samhällssystem eller studerar hur straffsystemen faktiskt kom att utformas under förhärskande straffteorier. (Här förekommer givetvis den sedvanliga reservationen: ,Vi kommer inte att fördjupa oss i den straffrättsteoretiska diskussion som tidigare förts i Sverige och på andra håll“ (s 159). En sådan ståndpunkt kan emellertid ifrågasättas i en idéskrift om straffrättsteoretiska principer. I inledningskapitlet ges för övrigt en nyttig om än kort historisk bakgrund.)

Arbetsgruppen borde väl åtminstone ha pekat på sina andliga läromästare och behandlat den klassiska straffskolan i relation till sin egen nyklassiska strafflära. Stor likhet föreligger exempelvis mellan arbetsgruppens straffprinciper och de som lanserades av Beccaria i Dei delitti $e$ delle pene 1764: Lagen, i synnerhet strafflagen, bör begränsas så långt som möjligt. Brottsprevention är viktigare än bestraffning. Straffet bör komma säkert, snabbt och stå i proportion till brottet. Man straffas för ett begånget brott och kan således inte dömas för tidigare begångna eller kommande brott, och hänsyn bör inte heller tas till personlighet eller övriga omständigheter.

Mycket av detta och annat upprepas i rapporten, ehuru ofta mindre konsekvent. När arbetsgruppen exempelvis förordar att den tilltalades prognos inte skall tillmätas betydelse vid påföljdsvalet, följer man Beccarias straffprincip att ingen skall dömas för kommande brott. När man emellertid vill att återfallet skall tillmätas en straffskärpande betydelse, gör man ett viktigt avsteg från den klassiska straffprincipen att ingen skall straffas för tidigare begångna brott. Varför gör arbetsgruppen här ett undantag från den annars så omhuldade principen att endast brottet skall ha betydelse för straffmätningen och låter brottslingens antecedentia spela en avgörande roll? Jag återkommer till gruppens syn på återfallet och dess betydelse (avsnitt 8).

32) Donald Cressey, Åtalsförhandling — en väg till rättvisa i Bondeson red, opus cit 1979. 
På samma sätt skulle man önska att rapporten hade berört strafftänkandet inom den nyklassiska rörelse som vuxit fram i USA på 70-talet och som den likaså har mycket gemensamt med. I Struggle for Justice (gjord för the American Friends Service Committee) protesterade man $t$ ex redan 1971 mot den judiciella diskretionen baserad på individualiserade åtgärder utifrån en behandlingsfilosofi. I Doing Justice (Committee for the Study of Incarceration, 1976), som framför straffprinciper som är nära besläktade med arbetsgruppens, utgick man från idealet att avskaffa fängelsestraffet men stannade vid att med kraft framhäva vikten av ett avsevärt minskat bruk av frihetsberövande påföljder och föreslår härvid bl a en maximering av frihetsstraffen till 5 år. I förordet framhåller man dessutom med skärpa att kommitténs rekommendationer bör ses som en paketlösning och om man inte tar dess konkreta förslag bör man inte heller anamma dess filosofi. Det är antagligen karakteristiskt att i följande amerikanska nyklassiska betänkande Fair and Certain Punishment (Task Force on Criminal Sentencing, 1976) har den ursprungliga målsättningen med minskat bruk av frihetsstraff kommit mer i bakgrunden och man har i högre grad övergått till tekniska frågor sammanhängande med översättning av brottens svårhet till olika straffskalor.

Arbetsgruppen borde också ha visat sin tacksamhetsskuld till den finska straffrättskommittén som för BRÅ tidigare presenterat sina tankar i Straffrättskommitténs betänkande. ${ }^{33}$ ) Anttila har pekat på de stora likheter både i straffilosofi och i konkreta reformförslag som föreligger mellan de båda betänkandena. ${ }^{34}$ )

Det är allmänt känt att straffet liksom brottet är beroende av olika ekonomiska och kulturella förhållanden i samhället. Det hade varit intressant om arbetsgruppen försökt att analysera vad dessa olika klassiska och nyklassiska strömningar kan ha gemensamt. Det förefaller mig exempelvis som om man i samtliga här nämnda fall har reagerat mot vad som uppfattats som alltför stränga straff. Upplysningstidens och Beccarias klassiska straffprinciper kan ses som en naturlig reaktion mot de synnerligen grymma och godtyckliga straffen i l'ancien régime. Nyklassicismen i USA kan på motsvarande sätt ses som en reaktion på de mycket långa och oftast icke tidsbestämda frihetsstraffen. I Finland har situationen delvis varit densamma med frihetsstraff

33) Rikosoikeuskomitean meitintö 1976:72. Betänkandet har senare i sin helhet översatts till svenska: Straffrättskommitténs betänkande, band 1 och 2, Helsingfors 1978. Se även Anttila, Ett förslag till strafflagsreform i Finland, NTfK 1977, 102-106 och Straffesystemer $i$ Nor-
den, NU-serien B 1977:25, s 89 ff.

34) Anttila, opus cit 1978, s $122 \mathrm{ff}$. 
som legat på en nivå som varit ca tre gånger så hög som i övriga nordiska länder. ${ }^{35}$ )

Jämfört med de länder där den klassiska och den nyklassiska straffläran använts som vapen mot synnerligen hårda och godtyckliga straff var den kriminalpolitiska situationen en annan i Sverige. Här hade den dåvarande justitieministern gett direktiv om att avskaffa de tidsobestämda frihetsberövandena och gjort officiella uttalanden om att drastiskt minska fängelsepopulationen. ${ }^{.6}$ ) Antalet fångar gick också på kort tid kraftigt ned. Utvecklingen har däremot senare varit den motsatta, varför vi nu åter har kommit upp i nästan samma nivå som tidigare. Orsakerna bakom denna nedgång och inte minst den senare uppgången vore värda ett närmare studium. Även om således Sverige i dag internationellt sett inte kan skryta med speciellt låga fångtal, är dock förhållandena radikalt annorlunda jämfört med t ex Finland och USA, och man har därför anledning fråga sig om den nyklassiska straffilosofin kan förväntas få en straffmildrande effekt även utifrån denna relativt sett mycket lägre straffnivå.

\section{Samband mellan straffilosofi och reformförslag}

Jag kommer så tillbaka till den inledningsvis ställda frågan om det finns något samband mellan den av arbetsgruppen utvecklade straffilosofin och dess framförda reformförslag. Jag tror man utan vidare kan påstå att det inte finns något självklart logiskt eller praktiskt samband mellan dess strafftänkande och dess kriminalpolitik.

Det kan i sammanhanget nämnas att reformförslag som i sina grunddrag starkt påminner om arbetsgruppens har presenterats från skilda hảll men med helt olika straffilosofisk bakgrund. Själv har jag t ex utifrån teorin om negativ individualprevention och med allmänpreventionsideologin som en begränsande faktor lanserat principen om minsta möjliga ingripande, kombinerad med en välfärdsideologi. ${ }^{37}$ ) Den norske Kriminalmeldingen menar att vår kunskap om straffens verkningar är mycket begränsad och vill av den anledningen inte bruka allmänpreventionen som teori för att legitimera straffen utan hänvisar i stället till andra värden som humanitet och rättvisa. Det deklareras öppet: „Det er $\mathrm{i}$ seg selv et mål å redusere bruken av straff. Særlig gjelder

35). Nils Christie, De fratagbare goder. En inntak til beskrivelse av verdiendringer over tid, Tidskrift for samfunnsforskning 1966, 119130.

${ }_{36}$ ) Justitieminister Lennart Geijer gjorde sitt berömda Runö-tal den 30 januari 1975. Se även Riksdagsprotokoll nr 39 § 6 från den 18 mars 1975.

37) För reformförslag se Bondeson, opus cit 1974 kap 16 och opus cit 1977 kap 9. 
dette bruken av frihetsstraff. Spesielt må man s $\varnothing$ ke å motvirke en sosialt skjev virkning av straffesystemet.“"36) Det danska betänkandet Alternativer til frihedsstraf utvecklar visserligen de skäl som kan åberopas mot användningen av frihetsstraff - humanitelshänsyn, frihetsstraffens skadliga verkningar, omvärderingen av egendomsbrotten och samhällsekonomiska hänsyn — men man inriktar sig framför allt på att mera pragmatiskt finna sådana metoder och sanktionsformer som direkt syftar till att minska bruket av frihetsstraffen. ${ }^{39}$ ) Det kan också påpekas att flera av den svenska arbetsgruppens reformförslag tidigare förts fram av ledamöter inom gruppen utan motsvarande strafftänkande. ${ }^{40}$ )

Jag menar med andra ord att den svenska kriminalpolitiska arbetsgruppen logiskt sett kunde ha lagt fram samma reformförslag utan någon klart uttalad straff- eller behandlingsteori eller utifrån helt andra teorier. Den kunde också ha utgått från en ren ideologi, kallad allmänprevention eller något annat.

$\mathrm{Nu}$ har emellertid arbetsgruppen presenterat en allmänpreventivt grundad straffteori, och nästa fråga blir då vilken överensstämmelse som finns mellan denna och de konkreta reformförslagen, praktiskt sett. Till skillnad från det danska betänkandet Alternativer til frihedsstraf görs i det svenska inga försök att beräkna vilka effekter den ena eller den andra kriminalpolitiska åtgärden kan tänkas få vad gäller exempelvis reduktionen av antalet fångar. Vi tvingas således spekulera.

Bland föreslagna konkreta reformer som syftar till att minska bruket av frihetsstraff kan nämnas slopande av straffminimum vid fängelse, generell sänkning av straffmaxima, och införande av nya påföljdsarter som intensivövervakning. Dessa åtgärder bör ceteris paribus leda till att fångpopulationen minskar.

Problemet blir att söka utvärdera vilka reella effekter dessa reformer kan tänkas få. Om man sänker straffminimum vid fängelse från en månad till en vecka, skulle detta kunna få en påtaglig effekt på antalet fångar, såvida inte domstolarna samtidigt börjar döma till kortare frihetsstraff $i$ stället för $t$ ex höga böter i större utsträckning än tidigare, då resultatet faktiskt skulle kunna bli det motsatta. Den nya påföljden intensivövervakning presenteras

ss) St. meld. $\mathrm{nr} 104(1977-78)$. Om kriminalpolitikken. Justis- og politidepartementet (citat s 14).

39) Alternativer til frihetsstraf - et debatoplæg. Betænkning nr. 806. København 1977. Se även Betænkning vedrørende nogle af- og nedkriminaliseringsspørgsmål. Betænkning nr. 650, København 1972.

$\left.{ }^{40}\right)$ Aspelin, Böter i stället för frihetsstraff, NTfK 1973, 53-72, och Utvecklingslinjer $\mathrm{i}$ svensk kriminalpolitik efter brottsbalkens införande, NTfK 1975, 97-122, och Förmögenhetsbrotten, BRA-rapport 1975:3 (med Aspelin som föredragande). Se även Den första stenen av Elwin, Heckscher \& Nelson, Stockholm 1975 (4: e revid uppl). 
som ett alternativ till fängelse, inom vilken dessutom traditionell straffmätning skall kunna praktiseras, men i realiteten är det möjligt att den endast kommer att ersätta de tidigare upprepade skyddstillsynsdomarna; med hänsyn till återfallets betydelse (se nedan) skulle den också kunna få den icke avsedda, motsatta effekten att snabbare leda till frihetsstraff.

En förutsättning för att de här nämnda straffreformerna skall få avsedd verkan är därför att lagstiftaren i alla avseenden helt lyckas styra domstolarna. Jag har redan ifrågasatt att påföljdsval och straffmätning fungerar enligt sådana rationella beslutsmodeller (avsnitt 5). Man kan givetvis säga - som en ledamot i arbetsgruppen muntligen formulerade det — att det krävs att reformerna följs upp med intensiv bevakning och kontroll. Han kastade även fram tanken att för detta ändamål skapa en påföljdsombudsman. Personligen tror jag emellertid inte att detta är realistiskt. Troligen är det heller inte önskvärt att på detta sätt hårt söka binda domstolarna.

De verkställande myndigheterna, inklusive domstolarna, kan ta en rad praktiska och humanitära hänsyn som lagstiftaren inte kan göra, och som tidigare framkommit verkar dylika anpassningar i allmänhet straffdämpande. I Nytt straffsystem vill man lagstiftningsvägen kraftigt reducera de verkställande myndigheternas möjligheter till dylika individualiserande åtgärder. Då arbetsgruppen vill att domstolarna vid påföljdsval och straffmätning skall ställa brottet $\mathrm{i}$ centrum och i princip bortse från brottslingen, torde detta exempelvis få som reell effekt att straffmildrande omständigheter ges väsentligt mindre utrymme. Förslaget att avskaffa den villkorliga frigivningen riskerar på motsvarande sätt att reellt ta bort möjligheter till strafflindring. Nådeinstitutet tycks arbetsgruppen ha glömt bort, men detta strider ju också mot dess klassiska principer och borde således avskaffas, vilket skulle innebära att en annan, icke oviktig möjlighet att förkorta straffen försvann. ${ }^{41}$ )

Det förefaller mig faktiskt finnas uppenbara risker för att arbetsgruppens reformidéer, trots dess progressiva avsikter, kan få en annan och sannolikt även motsatt effekt än den avsedda. Hänvisningar till allmänpreventionens krav har ju hittills brukat förekomma när lagstiftare eller domstolar vill höja straffen, icke när de vill sänka straffnivån. Gruppens straffprinciper vad gäller proportionalitet, enkelhet och förutsebarhet riskerar vad jag kan förstå snarast att leda till en upptrappning av hela straffsystemet. I någon mån kan detta kanske illustreras av rapportens

41) Förre justitieministern Geijer relaterade vid ett inlägg i en diskussionsafton kring Nytt straffsystem i Juridiska föreningen i Lund att av 2.000 nådeärenden per år hade $20 \%$ bifallits. 
trappstegsmodeller, vilka gäller såväl för påföljdssystemet i stort (s 408) som för reaktioner vid villkorsbrott (s 320). I nuvarande relativt sett mer individualpreventivt inriktade system kan domstolarna döma till villkorlig dom och speciellt till skyddstillsyn mer än en gång, och man kan likaså återkomma till villkorliga straff efter olika former av frihetsstraff. Dessa spiralliknande kretssystem har beskrivits vid det nordiska symposiet om upprepad brottslighet..22) Enligt föreliggande förslag skall emellertid trappan endast leda uppåt och det kan rimligen bara betyda straffskärpning.

Rent common-sense verkar det också märkligt att ett kriminalpolitiskt system som eftersträvar att alla brott skall bestraffas, att straffen alltid skall vara obehagliga och systematiskt upptrappas avseende stränghet skulle kunna få en strafflindrande effekt. Eftersom arbetsgruppen tydligen inte delat denna nära till hands liggande uppfattning, skall jag konkretisera med ett exempel som jag menar är tydligt och dramatiskt till sina effekter. Det gäller frågan om återfallets betydelse vid straffmätningen. Som tidigare framkom (avsnitt 6) gör arbetsgruppen här ett undantag från sin straffilosofi att domstolen skall sätta brottet i centrum och i princip bortse från brottslingen. Detta avsteg från Beccarias klassiska strafflära, att brottslingen icke skall straffas för tidigare begångna brott som redan sonats, förklaras med att återfallet definieras som en egenskap hos brottet i stället för hos brottslingen! Gruppen tycks i första hand mena att gärningens straffvärde ökar på grund av en kumulerad skuld och en härmed förtjänad ökad indignation..$^{43}$ )

Argumentationen torde bl a visa att det är omöjligt att abstrahera brottet från brottslingen — skuldbegreppet måste ju häftas

42) Det nordiska symposiet angående upprepad brottslighet har återgivits i NTfK 1976, vol 3-4.

43) Arbetsgruppen avvisar föreställningen att straffskärpning vid återfall skall vila på en behandlingstanke. Som motiv för straffskärpning anförs utöver skuldtanken $i$ någon mån också tanken om samhällsskydd. Ytterligare ett argument för att tidigare lagföringar skall ha inflytande på påföljdsbestämningen sägs vara att om återfall inte tillmäts betydelse vid straffmätningen, skulle detta leda till , strängare straff för förstagångsförbrytare“ (s 223). Denna tanka kan ju synas bestickande men är inte helt självklar. Om målsättningen verkligen är att sänka straffnivån generellt får man ta hänsyn härtill vid fastställande av straffskalorna. Argumentet skulle kanske vara riktigt om man samtidigt rekommenderade att påföljdstrappan började på en lägre nivå än eljest. Gruppen har emellertid knappast föreslagit några sådana nya former av mera lindriga sanktioner. Tvärtom vill den begränsa tillämpningen av átalsunderlătelse (s 429-431), eftersom detta institut uppenbarligen strider mot de klassiska straffprinciperna. Utvecklingen hittills har dock inneburit ett ökat utrymme för åtalsrestriktioner (se också åtalsrättskommitténs förslag i betänkandet Färre brottmål, SOU 1976:47; jfr även den amerikanska , diversion"-rörelsen). 
vid en individ. När man nu brutit mot principen att bortse från brottslingen, skulle man likaväl kunna ta nästa steg och oförbehållsamt fråga sig om orsakerna till återfallet. Enligt utredningens synsätt förefaller dock brottslingens ondska vara den enda förklaringen, och straffet skall enligt ett vedergällningstänkande därför bli så mycket hårdare. Andra orsaker kan emellertid tänkas. Enligt teorin om negativ individualprevention kan t o $\mathrm{m}$ det tidigare straffet ha ökat risken för återfall, och enligt ett sådant synsätt borde den straffades ,skuld“ härigenom minska i stället för att öka.44)

Idéhistoriskt är det intressant att lägga märke till att även om arbetsgruppens förslag vad gäller straffskärpningar vid återfall strider mot både Beccarias klassiska straffprinciper och senare nyklassiska i amerikansk och finsk tappning, har i den tillämpade klassiska straffläran praxis varit att skärpningar sker regelbundet vid återfall. Det är faktiskt först på senaste tid, i samband med individualpreventiv forskning och den $\mathrm{s} k$ behandlingsideologins död, som idén om återfallets minskade vikt vid straffmätningen fått någon praktisk betydelse. I Danmark har den generella regeln om återfallets betydelse eliminerats från strafflagen 1973 och i Sverige slopades återfallsregeln 1976.

Frågan om återfallets straffskärpande betydelse är viktig såväl principiellt som kanske i synnerhet strategiskt. Återfallsbrottslingarna svarar för en mycket stor del av den totala brottsligheten. ${ }^{45}$ ) Straffmätningsregler vid återfall får därför en betydande genomslagskraft. ${ }^{46}$ ) Genom att en så stor andel av de straffade återfaller och återfallsreglerna uttalar att straffet systematiskt skall skärpas, får arbetsgruppens förslag på denna punkt totalt sett en kraftigt straffskärpande effekt.

44) Bondeson, Stratifikationsprinciper bland intagna, NTfK 1976, $308-314$.

${ }^{45}$ ) Sverige har inte haft någon statistik som visar hur stor del av den totala brottsligheten som orsakas av de tidigare straffade. Ramsey Clark skriver: „Den viktigaste siffran inom hela kriminalstatistiken är den som säger oss att $80 \%$ av alla allvarliga brott begås av återfallsförbrytare, att fyra femtedelar av alla grövre brott begås av människor som rättsväsendet redan tidigare kommit i kontakt med." (Brott $i$ USA, Stockholm 1970, s 283). För svenskt vidkommande föreligger vissa teoretiska uppskattningar gjorda av Gösta Carlsson, Kriminalitetsnivå och belastningsfördelningar, $B R \AA ̊ P M$ 1975:1 och en empirisk studie av Persson, Inbrottstjuvar $i$ Stockholm, Stockholm 1976 (stencil).

46) Waaben har t ex illustrerat vilken genomslagskraft straffmätningsreglerna hade i Danmark under mitten av förra århundradet då "gentagelsestraffene... bevirkede en strenghed udover alle grænser", opus cit $1978 \mathrm{~b}, \mathrm{~s} 7$. 


\section{Slutord}

Även denna ytliga genomgång av den ambitiösa och slimulerande rapporten Nytt straffsystem torde utvisa att den inte innehåller mycket som kan beskrivas som nytt. Dess straffilosofi är i princip den klassiska som fördes fram för två hundra år sedan, innan kriminologin som vetenskap sett dagens ljus. Dess praktiska reformförslag ligger i tiden och har i allmänhet förts fram på annat håll. Den vise Salomos uppfattning, att intet nytt under solen, och säger någon ,se, detta är nytt" så har det redan skett förut, tycks åtminstone äga giltighet inom straffrättens område. Det bör emellertid samtidigt sägas att det är förtjänstfullt att arbetsgruppen samlat och systematiskt presenterat aktuella kriminalpolitiska reformidéer.

Arbetsgruppen hävdar att utredningen skall betraktas som en idéskrift och den har uppenbarligen uppnått sitt vällovliga syfte att inbjuda till debatt. Det är emellertid just mot denna bakgrund jag kritiserat rapporten för att relativt ensidigt ha fört fram en straffilosofi, där man undviker att framhålla komplexitetsgraden hos dess centrala begrepp, som t ex proportionalitet och skuld. Man kan givetvis ställa sig frågan vad man rimligen kan begära av en utredning. Arbetsgruppen har säkert arbetat under tidspress och den bör lovordas för att ha fått fram ett så digert och uppslagsrikt betänkande på så kort tid. Man kan inte gärna kräva att gruppen som sådan skulle ha gjort mer. Däremot kan man göra gällande att om syftet med utredningen var att väcka debatt kring viktiga kriminalpolitiska frågor, borde arbetsgruppen ha haft en annan sammansättning och troligen också prioriterat sina arbetsuppgifter på ett annat sätt.

Min allvarligaste kritik mot arbetsgruppen är att den inte mer ingående analyserar sambandet mellan rapportens straffilosofi och de föreslagna reformerna. Jag anser att det i realiteten finns lite överensstämmelse mellan dess filosofi och dess konkreta förslag och fruktar att de i och för sig i långa stycken utmärkta reformförslagen kan komma att sopas bort av de mer publikfriande parollerna. ${ }^{47}$ ) Det föreligger också en risk för att utred-

${ }^{47}$ ) Vissa tidningar har också varnat för att det bara blir den mera vulgära delen av budskapet, dvs att vi skall straffa i stället för att vårda, som går fram till den breda allmänheten och ger upphov till krav på hårdare tag; man pekar exempelvis på risken av hårdare behandling och längre straff om brottskurvan går uppåt eller särskilt avskyvärda våldsgärningar upprör sinnena (Folkbladet östgöten och Eskilstunakuriren; se även Aspelin, opus cit 1978, s 26). 
ningen kan sätta $\mathbf{i}$ gång en reaktionär utveckling ${ }^{48}$ ) genom att gruppens gammaldags strafftänkande kan utnyttjas av mer konservativa grupper, vilka inte med nödvändighet behöver skriva under på dess mer progressiva reformpolitiska program. ${ }^{49}$ )

Jag anser att arbetsgruppen borde ha observerat dessa problem och explicit ha varnat härför liksom man gjorde i Doing Justicerapporten. Utvecklingen i USA tycks också visa att den motsvarande s k ,,desert"-rörelsen i hög grad fångats upp av ,law and order"-grupperna. ${ }^{50}$ )

Rättsteori och rättshistoria har lärt oss att den formella rationaliteten inte räcker till ens då vi rör oss på det inom-juridiska planet. ${ }^{51}$ ) Rättssociologin har ytterligare visat att det kan vara en stor skillnad mellan "law in the book" och "law in action", dvs att det kan vara ett stort avstånd mellan intention och verklighet. ${ }^{52}$ ) Det förefaller mig som om arbetsgruppen inte tillräckligt tagit lärdom härav.

Ulla Bondeson

48) Kjellin har uttryckt liknande farhågor: „Arbetsgruppens resonemang är inte helt ofarligt. Om det godtas, kan det sätta igăng en djupt reaktionär utveckling, som sopar bort de framsteg som brottsbalken medförde. Såsom läget är idag är det personutredningen och den åtalades aktuella situation som gör det möjligt att tillämpa kriminalvård i frihet $i$ åtskilliga fall där beskrivningen av brottet närmast talar för frihetsstraff. Lägger man ökad vikt vid gärningens straffvärde och den enskildes ansvar, samtidigt som man fäster mindre vikt vid de personliga omständigheterna $\mathrm{i}$ övrigt, är risken stor att resultatet oavsett vad arbetsgruppen säger sig vilja åstadkomma — blir strängare och mer stereotypa straff, fler frihetsstraff, längre frihetsstraff och minskat intresse för andra påföljder." (opus cit, s 130).

49) Det kan som exempel nämnas att medan Dagens Nyheter och Aftonbladet uttalat klara betänkligheter vad gäller straffilosofin i Nytt straffsystem och varnat för att arbetsgruppens synsätt leder till ett inhumant system och för utvecklingen tillbaka, applåderas det reservationslöst av Svenska Dagbladet. Detta konservativa organ finner att „det råder en rentut sagt befriande brist på hymlande" och att det är ",alldeles kolossalt skönt att det blir sagt" (nämligen att straff skall kallas straff och vara obehagligt samt skall definieras som obehagligt). Hur tankarna naturligen vandrar vad gäller straffsystemet framgår av samma ledare. „Allt detta låter måhända brutalt. Men det gäller att hålla isär begreppen. Den principiella syn på straffsystemet som arbetsgruppen har behöver ingalunda kopplas till en sträng straffmätning“ (17 nov 1977). Att arbetsgruppens straffilosofi inte behöver leda till en strängare straffmätning innebär givetvis att den inte i verkligheten kan göra det, men uttalandet torde avslöja att tanken icke ligger så långt borta.

50) Sheldon Messinger skriver t ex: ,,The move toward 'just deserts' seems likely to encourage the imprisonment of a greater proportion of offenders, to the dismay of some of its proponents (but not of others who support it for just that reason)."

51) Angäende bl a komplikationsgraden vid lagtolkning, se Aleksander Peczenik, Juridikens metodproblem, Stockholm 1974; se även Kan juristerna tänka rationellt? i Bondeson red, opus cit 1979.

52) Se Lawrence Friedman, The Legal System, New York 1976. 